\title{
The parakeet Brotogeris tirica feeds on and disperses the fruits of the palm Syagrus romanzoffiana in Southeastern Brazil
}

\author{
Ivan Sazima ${ }^{1,2}$ \\ ${ }^{1}$ Departamento de Zoologia e Museu de História Natural, Universidade Estadual de Campinas - UNICAMP, \\ CP 6109, CEP 13083-970 Campinas, SP, Brasil \\ ${ }^{2}$ Autor para correspondência: Ivan Sazima, e-mail: isazima@gmail.com,www.unicamp.br
}

Sazima, I. The parakeet Brotogeris tirica feeds on and disperses the fruits of the palm Syagrus romanzoffiana in Southeastern Brazil. Biota Neotrop., vol. 8, no. 1, Jan./Mar. 2008. Available from: <http://www.biotaneotropica. org.br/v8n1/en/abstract?short-communication+bn01008012008>.

Abstract: Small psittacids remain unrecorded as dispersal agents of palm fruits in Brazil. I record here the plain parakeet (Brotogeris tirica), an Atlantic forest endemic, feeding on and dispersing the fruits of the palm Syagrus romanzoffiana at Ubatuba, northern coast of São Paulo, Southeastern Brazil. The birds removed the fruit and carried it away from the mother-tree in about $40 \%$ of the feeding records. While perched on trees and shrubs of the understorey, the parakeets removed and ingested most of the mesocarp, dropping the partly consumed fruit. As the parakeets damaged no the embryo and may feed at a distance from the mother-tree, they act as primary dispersal agents. This is the first substantiated record of a small Neotropical psittacid as a stomatochorous dispersal agent of palm fruits the size of $A$. romanzoffiana drupes.

Keywords: Bird-plant symbiosis, Psittacidae, Arecaceae, feeding behaviour, synzoochory.

Sazima, I. O periquito Brotogeris tirica come e dispersa os frutos da palmeira Syagrus romanzoffiana no sudeste do Brasil. Biota Neotrop., vol. 8, no. 1, jan./mar. 2008. Disponível em: <http://www.biotaneotropica. org.br/v8n1/pt/abstract?short-communication+bn01008012008>.

Resumo: Psitacídeos de pequeno porte não constam como dispersores de frutos de palmeiras no Brasil. Registro aqui o periquito-rico (Brotogeris tirica), endêmico da mata Atlântica, alimentando-se em e dispersando frutos da palmeira Syagrus romanzoffiana em Ubatuba, litoral norte do Estado de São Paulo. As aves removiam o fruto e, em cerca de $40 \%$ dos registros alimentares, carregavam-no à distância da árvore-mãe. Empoleirados em ramos de arvoretas e arbustos no sub-bosque, os periquitos retiravam e ingeriam a maior parte do mesocarpo, deixando cair o resto do fruto. Uma vez que estas aves se alimentam sem danificar o embrião e podem fazê-lo a certa distância da árvore-mãe, agem como dispersores primários. Este é o primeiro registro documentado de um psitacídeo Neotropical de pequeno porte como dispersor estomatocórico de frutos de palmeira com as dimensões das drupas de $S$. romanzoffiana.

Palavras-chave: Simbiose ave-planta, Psittacidae, Arecaceae, comportamento alimentar, sinzoocoria. 


\section{Introduction}

Parrots, parakeets, and macaws - family Psittacidae - feed mostly on seeds, fruits, and flowers including petals and nectar (e.g., Forshaw 1989, Pizo et al. 1995, Collar 1997, Sick 1997, Ragusa-Neto 2004). Nevertheless, parrots and their kin are primarily seed-predators, as they feed on the embryo of the fruits they forage on (Collar 1997,Sick 1997) and thus rarely act as primary fruit dispersers. Seeds occasionally dispersed by psittacids are tiny, such as those of Ficus spp., Cecropia spp., and Muntingia calabura and even in these instances the dispersed seeds form a small portion compared with those destroyed while the parrots feed on the fruits (Janzen 1981, Collar 1997).

The Neotropical parakeets grouped in the genus Brotogeris form an assemblage of small psittacids (16-25 cm, 52-80 g, see Collar 1997) that feed on fruits, flowers, nectar, algae, insects, and snails (Collar 1997, Ragusa-Neto 2004, Paranhos et al. 2007). In Southeastern Brazil, Brotogeris chiriri and B. tirica are recorded to feed on palm fruits, of which they eat the pulp (Galletti 1997, Ragusa-Neto 2004, Paranhos et al. 2007). None of the latter authors mention the possibility that Brotogeris parakeets might disperse palm fruits, especially the larger ones. However, Christianini (2006) states that $B$. chiriri feeds on the pulp of the exotic palm Archontophoenix cunnighamiana and drops the "seed" under the mother-tree.

I record here the plain parakeet (Brotogeris tirica), an Atlantic forest endemic (Collar 1997, Sick 1997) feeding on and dispersing the fruits of the palm Syagrus romanzoffiana in the coastal lowland forest at São Paulo, Southeastern Brazil. Besides general observations on the parakeets' behaviour, four main questions were focused in this short study: 1) Which techniques the birds use to feed on the palm fruits? 2) Are the fruits eaten by the birds on the mother-tree or carried to be consumed away from it? 3) If carried away, which is the maximal observable distance the birds carry the fruits? and 4) May the birds be regarded as dispersal agents of this palm species?

\section{Material and Methods}

Field records were made at the Praia do Estaleiro $\left(23^{\circ} 20.255^{\prime} \mathrm{S}\right.$ and $44^{\circ} 53.014$ ' W) in Ubatuba, São Paulo state, Southeastern Brazil. The study site is a mix of wetland and mangrove vegetations close to a stream. One focal-tree (cf. Marcondes-Machado \& Argel-de-Oliveira 1988) of the palm Syagrus romanzoffiana was observed on 11 July 2007 and two other focal-trees were observed on 13 of the same month. The behaviour of the parakeets was initially assessed with naked eye at a distance of about 10-15 m, and then observed through binoculars and a $300 \mathrm{~mm}$ auto-phocus telephoto lens. "Ad libitum" and "behaviour" sampling rules (Martin \& Bateson 1986) were used throughout the observational sessions, which lasted 12 minutes (11 July) and 47 minutes (13 July), between 1140 e 1245 hours. Each palm fruit consumed on the palm tree (even if partially) or removed to be consumed away from it was defined as a feeding record. Potential damage to the embryos was examined by checking the integrity of the endocarp (the viability of the embryos was not examined as the fate of the propagules is beyond the scope of this study). Digital photographs were taken as vouchers and used for further analyses and description of the birds' behaviour. Seedlings and/or saplings of the palm were searched for at the points where the parakeets were recorded feeding on fruits in the understorey. In the laboratory the greatest diameter of 17 fresh drupes and the thickness of the endocarp of 12 additional ones were taken with a calliper to the next tenth of a millimetre. Additionally, the nostril-bill tip distance (see Sick 1997) of two specimens of B. tirica preserved in the ornithological collection of the Museu de História Natural, Universidade Estadual de Campinas (ZUEC 2031 and unnumbered) was taken in the same way.

\section{Results}

Brotogeris tirica arrived alone ( $\mathrm{N}=1)$, in couples $(\mathrm{N}=2)$, or small flocks of up to about 10 individuals $(\mathrm{N}=2)$ to Syagrus romanzoffiana trees. Upon arrival the parakeets landed on the infructescences (mostly on the branchlets bases) or directly on the fruits. They perched and moved deftly around and chose certain fruits to feed on. Three main feeding techniques were recorded: 1- feeding on a fruit still attached to a branchlet of the infructescence (Figure 1a; $N=13$ ); 2- feeding on a fruit previously removed with the bill from a branchlet and held with the feet (Figure 1b; N = 9); 3- removing the fruit, putting it in the bill with the feet and carrying it away from the mother-tree (Figures 1c and $2 \mathrm{a}, \mathrm{b} ; \mathrm{N}=17)$. The fruits were removed with biting movements at their attachment on the branchlet. To feed on a fruit the birds removed the epicarp ("peel") and fed on portions of the mesocarp ("pulp"), which they bit and chewed (Figures 1a, b and 2b). Sometimes they spat out pieces of husk. After a while, the partly consumed fruit was dropped and the bird came for a new one.

In all feeding records in which the parakeets used the foot to hold the fruit while feeding on it or to put it in the bill to be carried away $(\mathrm{N}=26)$ the birds used the left one.

Of the 39 feeding records, the parakeets either fed on the mothertree $(\mathrm{N}=22 ; 56.41 \%)$ or removed the fruit and flew away a distance $(\mathrm{N}=17 ; 43.58 \%)$. While feeding either on the palm tree or elsewhere in the understorey, the parakeets remained silent. The birds that flew to consume the fruits elsewhere were found by spotting the orange colour of the palm fruits, since the parakeets' green plumage blended with the understorey vegetation they perched on (Figure $2 b$ ). The distances the parakeets were found feeding on the palm fruits in the understorey varied 10.3-40.1 $\mathrm{m}(\mathrm{x}=22.14 ; \mathrm{sd}=13.80 ; \mathrm{N}=9)$ from the mother-tree of which the birds removed the fruits. No dropped fruit showed damage to the endocarp. A seedling and a sapling (Figure 2c) were found $10.2 \mathrm{~m}$ and $12.1 \mathrm{~m}$ from the nearest adult $S$. romanzoffiana tree, respectively.

Three agonistic encounters between two $B$. tirica individuals (likely not the same ones in the three bouts) were recorded in the observational session on 13 July. These "quarrels" occurred only when two birds went much close to each other when choosing fruits to feed on. During the aggressive bouts the birds vocalised loudly and lunged at each other with open bills (Figure 3). No actual harm was observed, and one of the birds always moved away after such a dispute.

Syagrus romanzoffiana fruits' diameter was 18.1-20.3 mm $(\mathrm{x}=19.21 ; \mathrm{sd}=0.62 \mathrm{~mm})$; endocarp's wall thickness was $2.8-3.6 \mathrm{~mm}$ $(\mathrm{x}=3.08 ; \mathrm{sd}=0.22)$; nostril-bill tip distances of the two preserved B. tirica parakeets were 18.3 and $17.2 \mathrm{~mm}$.

\section{Discussion}

The fruits (= drupes) of Syagrus romanzoffiana are recorded as food for at least two psittacid species in Brazil, Myiopsitta monachus (Fallavena \& Silva 1988) and Brotogeris chiriri (Paranhos et al. 2007). The feeding techniques I recorded for $B$. tirica while feeding on $A$. romanzoffiana drupes roughly correspond to those described by Paranhos et al. (2007) for B. chiriri while feeding on a variety of fruits in a detailed study on the feeding behaviour of this latter species. The use of the left foot only to pick up or handle food recorded for $B$. tirica in the present study agrees with the notion for tendency of "left-handedness" in several psittacid species, although this is still a controversial issue (see Friedman \& Davis 1938, McNeil et al. 1971, Collar 1997, Sick 1997, Paranhos et al. 2007). These latter authors observed about $70 \%$ of "left-handedness" for B. chiriri feeding records in the wild (Paranhos et al. 2007). 

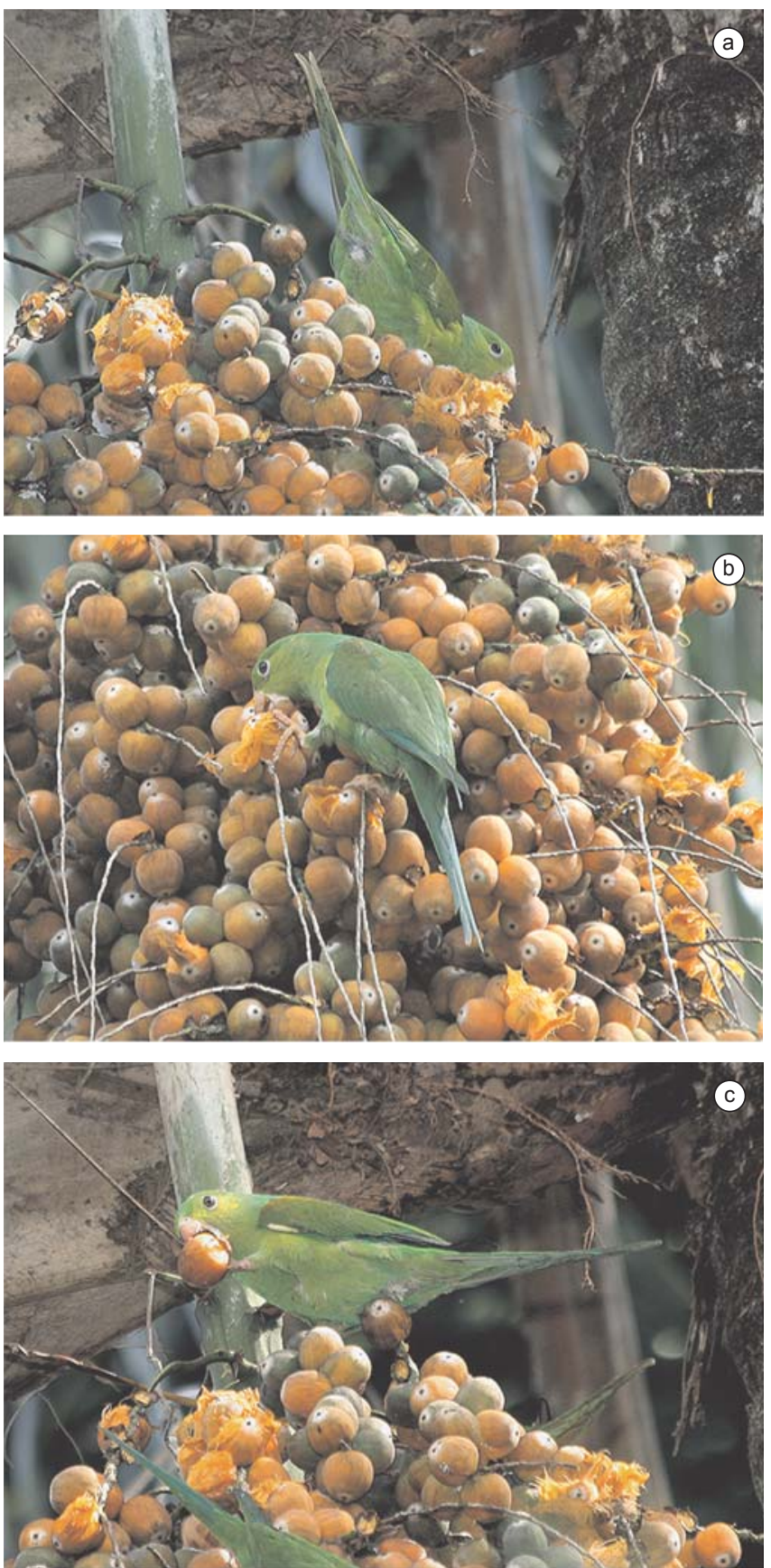

Figure 1. Three feeding techniques of the parakeet Brotogeris tirica while consuming the fruits of the palm Syagrus romanzoffiana: a) a bird feeds on a fruit still attached to a branchlet of the infructescence; $b$ ) another individual removed the fruit and holds it with its foot while feeding; and c) a parakeet puts a fruit in its bill to feed on it away from the mother-plant - note use of left foot to hold the fruit by both birds.

Figura 1. Três técnicas alimentares do periquito Brotogeris tirica para consumir os frutos da palmeira Syagrus romanzoffiana: a) um indivíduo consome um fruto ainda preso ao ramo da infrutescência; b) outro indivíduo removeu o fruto e o segura com o pé enquanto come; e c) um indivíduo coloca um fruto no bico para se alimentar distante da árvore-mãe - note uso do pé esquerdo em ambos os indivíduos.

Transport of fruits removed from the mother-tree is only mentioned en passant for $B$. chiriri (Paranhos et al. 2007) although for $B$. tirica there are records of transporting infructescence pieces of Cecropia spp., which bear minute seeds (Marcondes-Machado \&
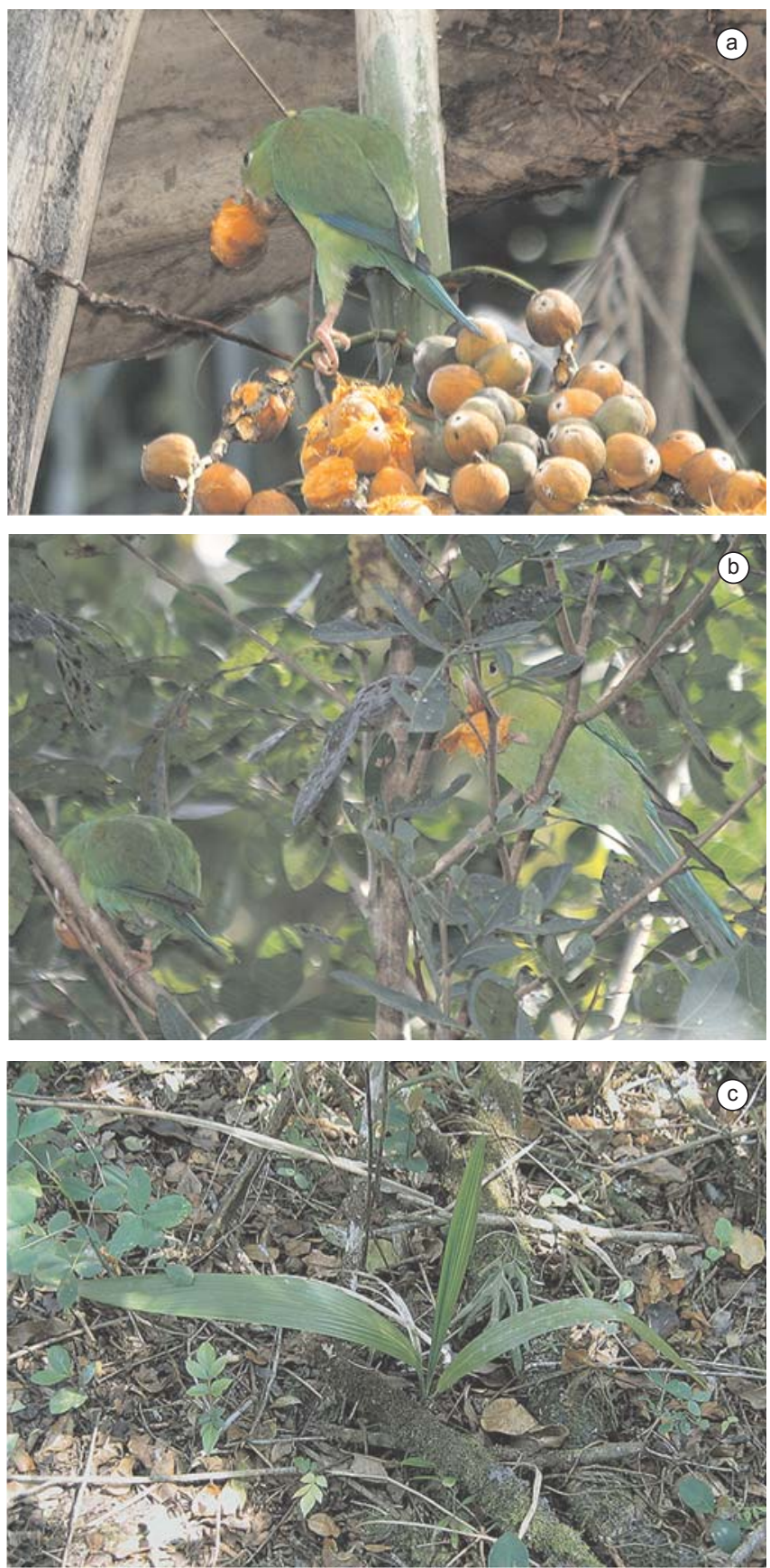

Figure 2. a) A B. tirica parakeet moves on the infructescence with a fruit in its bill to fly from the mother-plant; b) two parakeets perched on shrubs in the understorey hold $S$. romanzoffiana fruits while feeding on the mesocarp - note use of the left foot to hold the fruit by both birds; and c) a S. romanzoffiana sapling found $12.1 \mathrm{~m}$ from the nearest adult palm tree.

Figura 2. a) Um periquito $B$. tirica caminha sobre a infrutescência com um fruto no bico, para voar da árvore-mãe; b) dois periquitos pousados em arbustos de sub-bosque seguram frutos de $S$. romanzoffiana, enquanto consomem o mesocarpo - note uso do pé esquerdo, por ambos os indivíduos, para segurar os frutos; e c) muda de $S$. romanzoffiana encontrada a 12,1 m de distância da palmeira adulta mais próxima.

Argel-de-Oliveira 1988). However, as both B. tirica and B. chiriri are regarded mostly as seed predators (Marcondes-Machado \& Argel-de-Oliveira 1988, Paranhos et al. 2007) the fate of the transported pieces remains to be evaluated. In the present study, 


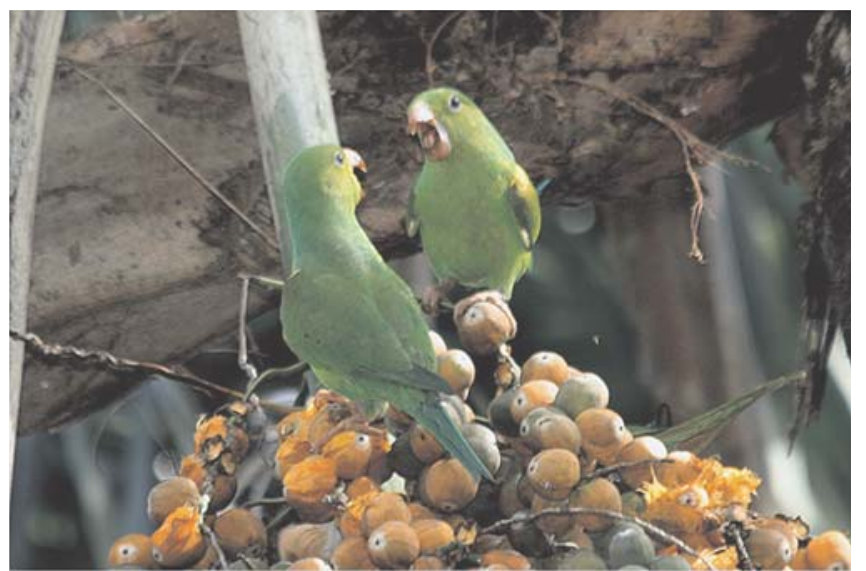

Figure 3. Two B. tirica parakeets quarrel while on a $S$. romanzoffiana infructescence - note that both birds hold a fruit with the left feet.

Figura 3. Dois periquitos B. tirica em disputa numa infrutescência de $S$. romanzoffiana - note que ambos estão segurando um coquinho com o pé esquerdo.

about $40 \%$ of the palm fruits were carried for a distance from the mother-tree by $B$. tirica individuals. Since these parakeets feed on the external parts of the fruit only and were unable to break through the thick and hard endocarp that harbours the embryo (pers. obs.), they might be classified as dispersal agents even if they were to drop the drupes under the mother-plant. The drupes dropped to the ground may be regarded as a form of dispersal roughly equivalent to barochory (dispersal by weight only, see van der Pijl 1982). Secondarily, the drupes may be carried away from the mother-tree by rain wash (hydrochory) or some animal foraging on the ground (zoochory). However, the parakeets carrying the drupes to observable distances of up to $40 \mathrm{~m}$ from the mother-tree would qualify $B$. tirica as primary dispersal agents of $A$. romanzoffiana at certain localities. Moreover, these parakeets may have the potential to carry the fruits farther than the distances recorded here, although this remains to be verified. The finding of a seedling and a sapling away from any adult palm of this species seems to strengthen the dispersal role, even if occasional, of these parakeets (however, any other dispersal type cannot be ruled out here).

The dispersal process that involves birds carrying plant propagules in their bills is called stomatochory, a type of synzoochory (van der Pijl 1982). The size of A. romanzoffiana drupe (about $20 \mathrm{~mm}$ ) and the size of $B$. tirica bill (the same size or slightly lower) makes likely that this fruit type is near the maximal size this parakeet would be able to carry in its bill. Thus, this is the first substantiated record of a small Neotropical psittacid that acts as a stomatochorous dispersal agent of palm fruits the size of $A$. romanzoffiana drupes.

\section{Acknowledgments}

To Marlies Sazima for her ever supporting love and help with botanical names and bibliography. An anonymous reviewer offered several suggestions to improve the manuscript. The CNPq provided essential financial support.

This research was partially supported by the State of São Paulo Research Foundation (FAPESP) as part of the Thematic Project Functional Gradient (Process Number 03/12595-7), within the BIOTA/ FAPESP Program - The Biodiversity Virtual Institute (www.biota.org. br). COTEC/IF 41.065/2005 and IBAMA/CGEN 093/2005 permits.

\section{References}

CHRISTIANINI, A.V. 2006. Fecundidade, dispersão e predação de sementes de Archontophoenix cunninghamiana $\mathrm{H}$. Wendl. \& Drude, uma palmeira invasora da Mata Atlântica. Rev. Bras. Bot. 29:587-594.

COLLAR, N.J. 1997. Family Psittacidae (parrots). In: Handbook of the birds of the world. Vol. 4. Sandgrouses to cuckoos (J. del Hoyo, A. Elliot \& J. Sargatal, eds.). Lynx Edicions, Barcelona, p. 280-477.

FALLAVENA, M.A.B. \& SILVA, F. 1988. Alimentação de Myiopsitta monachus (Boddaert, 1783; Psittacidae, Aves) no Rio Grande do Sul, Brasil. Iheringia 2:7-11.

FORSHAW, J. M. 1989. Parrots of the world. $3^{\text {rd }}$ ed. Landowne Ed., Willoughby.

FRIEDMANN, H. \& DAVIS, M. 1938. "Left-handedness" in parrots. Auk 55:478-480.

GALLETTI, M. 1997. Seasonal abundance and feeding ecology of parrots and parakeets in a lowland Atlantic forest, Brazil. Ararajuba 5:115-126.

JANZEN, D.H. 1981. Ficus ovalis seed predation by an orange-chinned parakeet (Brotogeris jugularis) in Costa Rica. Auk 98:841-844.

MARCONDES-MACHADO, L.O. \& ARGEL DE OLIVEIRA, M.M. 1988. Comportamento alimentar de aves em Cecropia (Moraceae) em Mata Atlântica, no Estado de São Paulo. Rev. Bras. Zool. 4:331-339.

MARTIN, P. \& BATESON, P. 1986. Measuring behaviour, an introductory guide. Cambridge University Press, Cambridge.

McNEIL, R., RODRIGUEZ, R. J. \& FIGUERA, D.M. 1971. Handedness in the brown-throated parakeet Aratinga pertinax in relation to skeletal asymmetry. Ibis 109:493-497.

PARANHOS, S.J., ARAÚJO, C.B. \& MARCONDES-MACHADO, L.O. 2007. Comportamento alimentar do periquito-do-encontro-amarelo (Brotogeris chiriri) no interior do estado de São Paulo, Brasil. Rev. Bras. Ornitol. 15(1):95-101.

Van der PIJL, L. 1982. Principles of dispersal in higher plants. SpringerVerlag, Berlin.

PIZO, M.A., SIMÃO, I. \& GALLETTI, M. 1995. Diet and flock size of sympatric parrots in the Atlantic forest in Brazil. Ornitol. Neotrop. 6:87-95.

RAGUSA-NETO, J. 2004. Flowers, fruits and the abundance of the yellowchevroned parakeet (Brotogeris chiriri) at a gallery forest in the south Pantanal. Braz. J. Biol. 64(4):371-382.

SICK, H. 1997. Ornitologia brasileira. $2^{\text {a }}$ ed. Editora Nova Fronteira, Rio de Janeiro. 